\title{
Revisões da masculinidade sob ditadura: Gabeira, Caio e Noll
}

\author{
Idelber Avelar ${ }^{1}$
}

Vários textos memorialísticos e ficcionais revisitaram o tema da masculinidade durante o ocaso do regime militar, no período conhecido como Abertura, na passagem da década de 1970 para a de 1980. Contemporâneos da consolidação do movimento gay brasileiro, do começo da entrada massiva de mulheres de classe média à força de trabalho remunerada e da lei do divórcio, esses textos revisitaram, criticaram e responderam a um conjunto de operações reais e simbólicas realizadas pela ditadura militar sobre as experiências e representações do gênero.

A ditadura se ancorava, por certo, numa leitura masculinista e fálica do mundo: desbravar, entrar, penetrar foram imagens constantes na linguagem de Golbery do Couto e Silva e de outros ideólogos do regime, em especial com referência à Amazônia. A masculinidade militar era ostensivamente homofóbica, mas também, por definição, homossocial, posto que marcada pela ausência da mulher. ${ }^{2}$ A voz do regime era decididamente masculina. Na esquerda que combatia a ditadura, uma concepção franciscana de masculinidade a associava ao sacrifício e à capacidade de suportar a tortura incólume. Na cultura de massas, desde o Tropicalismo e depois com grupos como Secos \& Molhados, encontravam expressão masculinidades não hegemônicas gay, andróginas, bissexuais, travestidas. No jornalismo, inaugurava-se em 1976 a primeira coluna para o público gay, assinada por Celso Cury na Última Hora, de São Paulo, de vida breve, pois denunciada por "atentado à moral e aos bons costumes" (Green, 2006, p. 167). Processos

\footnotetext{
${ }^{1}$ Doutor em literatura latino-americana e professor de literaturas hispano-americanas e brasileira na Tulane University, Nova Orleans, EUA. E-mail: idelberavelar@gmail.com

${ }^{2}$ Homossocialidade, homoafetividade e homossexualidade são termos que não se confundem ao longo deste ensaio, e devem ser tomados ao pé da letra: o primeiro termo designa os espaços regidos por mecanismos de socialização exclusivos para homens e o segundo designa um terreno de intercâmbio afetivo que pode ou não coincidir com a orientação sexual designada pelo terceiro. Com frequência - é o caso na obra de Caio Fernando Abreu, como se verá -, a homoafetividade atravessa e desestabiliza a fronteira supostamente estável entre orientações sexuais hétero e homo. Para os conceitos de masculinidades hegemônica e não hegemônica, usados neste ensaio, ver Connell (2005 [1995]).
} 
como a crescente visibilidade das travestis e dos michês, a abertura de discotecas e saunas, e a emergência do movimento de liberação gay produziam a sensação de revolução nas concepções dominantes de masculinidade (Green, 1999, p. 251-256 e 272-77). As memórias do exílio passavam a incluir narrativas de mulheres, que relatavam desde como, nas organizações de oposição à ditadura, "a mulher funcionava como o homem da casa, ou seja, éramos nós que, por questões de segurança, mantínhamos nossos companheiros" até histórias de mulheres condenadas a uma peregrinação por serem casadas com ativistas de esquerda e portanto reduzidas a ser "sombra do companheiro". ${ }^{3}$ Essas narrativas mostram um mundo bem diferente dos relatos masculinos do exílio, na medida em que estão consideravelmente mais atentas ao que acontece com os papéis de gênero.

A narrativa, testemunhal ou de ficção, teve em Fernando Gabeira, Caio Fernando Abreu e João Gilberto Noll três pontos de inflexão do tema na passagem da década. Gabeira foi importante inclusive na medida em que sobredimensionou seu próprio papel e conseguiu, com esse gesto, impor uma das interpretações dominantes da suposta revolução na masculinidade que teria tido lugar ali, com sua chegada do exílio, a tanga e as memórias de O que é isso, companheiro? (1979), Crepúsculo do macho (1980) e Entradas e bandeiras (1981). Naquele momento, Noll era pouco conhecido, mas já publicara um livro de contos notável, $O$ cego e a dançarina (1980), que ganharia mais importância à luz de sua carreira de três décadas e meia ininterruptas de novelas e romances. Por sua vez, Caio Fernando Abreu, de Inventário do irremediável (1970) e O ovo apunhalado (1975) a Morangos mofados (1982), destacara zonas de indeterminação entre homo e heterossexualidade, apreendendo nelas mecanismos essenciais do funcionamento da homofobia. O exilado das memórias-testemunho, o estreante que publicara um livro de contos insólito, único para a época (não realista, não fantástico, não regionalista) e o contista que chegava ao ápice de uma carreira já então notável articularam algumas das reflexões mais originais sobre a masculinidade na virada daquela década. ${ }^{4}$

\footnotetext{
3 "Maricota da Silva: abril de 1978" e "Vânia: janeiro de 1977" (Costa et al., 1980, p. 41 e 111 , respectivamente).

${ }^{4}$ Sobre a literatura brasileira na década precedente há uma abundante bibliografia. Pela abrangência do material apresentado e pela fecundidade das hipóteses exploradas, ver Süssekind (1985) e Dalcastagnè (1996).
} 


\section{Gabeira ou a hipérbole autorrealizada}

Com suas memórias, sua própria carreira parlamentar posterior e o auxílio de um filme de Bruno Barreto, Gabeira instalou um relato histórico marcado pela ideia de um antes e um depois, sendo este um momento de libertação associado pelo autor à sua própria narrativa e ao seu próprio retorno ao país. Parece-me correto dizer que Gabeira exagera seu papel, como outros estudos já demonstraram (ver em especial Ridenti et al., 1997). Mas também é correto dizer que esse exagero de certa forma deixa de sê-lo quando a narrativa produz o efeito performativo de gerar o próprio peso, a centralidade do personagem sobre quem ela antes hiperbolizara. Gabeira seria então o caso de uma narrativa autobiográfica que ganha importância exatamente na medida em que exagera o papel de seu autor - e é assim porque esse exagero se torna fundamento de uma leitura que está entre as dominantes acerca do que mudou na masculinidade no Brasil na virada dos setenta 70 para os 80 .

Como enfatizava o Gabeira daquela época, havia muito a revisar na incapacidade da esquerda de lidar com questões culturais e de comportamento. Contudo, as fórmulas pop de Gabeira cumpriram o papel de reduzir os fenômenos sociais ao seu menor denominador, com o resultado de apresentar o desbunde do final dos anos 70 como uma subversão sem precedentes. Ao fazer alusão à escolha pela luta armada na década anterior, Gabeira toma o que havia sido uma sensação comum entre militantes jovens e recentes como ele e faz disso uma descrição de todo o movimento:

O sonho de muitos de nós era o de passar logo para um grupo armado. Em nossa mitologia particular, conferíamos aos que faziam esse trabalho todas as qualidades do mundo. Sair do movimento de massas para um grupo armado era como sair da província para a metrópole, ascender de um time da terceira divisão para o campeonato nacional (Gabeira, 1981, p. 86).

Na realidade, boa parte da liderança das organizações de esquerda da época tinha claro que a passagem de um movimento de massas a uma ação armada isolada por uma autointitulada vanguarda representava uma perda de ímpeto na resistência à ditadura. Não importa o quão idealizada tenha sido sua apresentação dessa escolha, o "nós" de Gabeira incluía muito menos gente do que imaginariam 
aqueles que não têm notícias do papel marginal e lateral de Gabeira na resistência à ditadura (e não poderia ter sido de outra forma, dados a juventude e o caráter recente da militância do autor na época dos fatos narrados). No entanto, nenhum livro fez mais que $O$ que é isso, companheiro? para disseminar a ideia de que as questões culturais, de comportamento e de gênero haviam sido completamente obliteradas pela esquerda nos anos 60 e emergido de forma triunfante no fim dos anos 70, em grande parte - e isso não há que se dizer explicitamente no livro - como parte da intervenção do próprio Gabeira. Além das hipérboles contidas em $O$ que é isso, companheiro?, às quais me dediquei num trabalho anterior (Avelar, 2012), ${ }^{5}$ Crepúsculo do macho (1980), sobre seu exílio na Suécia e no Chile, e Entradas e bandeiras (1981), dedicado ao seu regresso ao Brasil, continuaram a marca registrada de Gabeira de retratar uma esquerda rançosa e homogênea contra a qual o seu discurso aparecia como expressão de uma liberação sem precedentes.

Entradas e bandeiras nos dá uma ideia bastante clara de como Gabeira via seu próprio papel. Uma forma verbal bastante reiterada no livro é o futuro do pretérito composto, através do qual o protagonista sistematicamente se coloca no lugar de seus compatriotas para fantasiar "o que eles teriam pensado", para imaginar que eles não teriam sido capazes de compreender que sua presença era o prenúncio de uma transformação revolucionária de valores. Ao perder um voo para Aracaju, onde aconteceria um debate, Gabeira imagina "patrulhas ideológicas paradas no aeroporto, vestidas com aqueles chapéus de couro dos cangaceiros, batendo seu fuzil no asfalto da pista e gritando: quem puxa fumo, perde o rumo, quem puxa fumo, perde o rumo" (Gabeira, 1981, p. 115). Quando um amigo de esquerda lhe confia sua preocupação de que uma matéria sobre ele, publicada no jornal Última Hora, poderia não ser muito positiva, Gabeira pressupõe que se tratava de sua masculinidade polêmica:

se Última Hora fizesse alguma alusão sobre minha masculinidade, não iria me defender com o velho argumento liberal de que não se deve tocar na vida particular das pessoas [...] Há muitos anos que nada tinha a ver com um sistema que oprimia as pessoas e muito menos com uma visão da sexualidade que era a outra face dessa opressão (Gabeira, 1981, p. 85).

\footnotetext{
${ }^{5}$ Os três parágrafos que seguem, sobre Entradas e bandeiras, canibalizam trechos desse ensaio.
} 
A confiança com a qual Gabeira afirma que já não tem nada a ver o sistema opressivo sexista já diz tudo o que se deve saber acerca de como o ex-guerrilheiro viu seu regresso ao Brasil.

Em temas como os movimentos ecológico, afro-brasileiro ou de mulheres, Entradas e bandeiras mostrava um exilado que voltava a um país que já não conhecia muito bem, apesar de ele não parecer tê-lo percebido. Ao relatar seu encontro com Gilberto Gil, Gabeira fala com aprovação da volta de Gil, então recente, às suas raízes africanas. Em consequência disso, Gabeira passa a manifestar seu desejo de uma presença mais decisiva do movimento negro com a seguinte pergunta: "Quando é que voltariam os amigos negros que se foram para o exterior, a fim de transmitir a experiência aprendida em outras terras?" (Gabeira, 1981, p. 120). Parece ter escapado a Gabeira a possibilidade de que os afro-brasileiros que nunca haviam saído do país já estivessem ocupados construindo um poderoso movimento cultural e político havia mais de uma década. Outro exemplo revelador de como Gabeira viu seu papel no regresso foi seu comentário sobre um debate de que participaria na Amazônia: "Ali não seria necessário falar da importância da ecologia, pois o movimento mais importante era exatamente a defesa da Amazônia" (Gabeira, 1981, p. 126).

É de se notar que um intelectual que acabava de desenvolver preocupações ecológicas não pensasse na possibilidade de que a ecologia era um tema apropriado de conversa precisamente porque ele poderia aprender algo de um movimento que tinha uma longa história e sólidos laços com seu ambiente. Inclusive a crítica de Gabeira aos sonhos grandiosos da esquerda parece tê-lo levado a uma percepção um pouco inflada de seu papel: "Minha passagem não aumentou o nível de consciência e de organização da classe operária, nem tornou diretamente mais próximo o fim do sistema capitalista. Mas conseguira introduzir uma série de temas importantes para a felicidade das pessoas, temas que não podem esperar por uma incerta e longínqua revolução proletária" (Gabeira, 1981, p. 165). Se é verdade que o parágrafo seguinte reconhece que ele não foi o introdutor desses temas, Gabeira não deixa de comentar que o que havia no Brasil antes de sua chegada eram "sementes de minhas posições". O certo é que havia bem mais que sementes das posições de Gabeira no Brasil dos anos 70, e nesse sentido é notável que praticamente nada do mundo das masculinidades não hegemônicas que se constituíam ali tenha 
encontrado eco nos textos de Gabeira. ${ }^{6}$ As declarações ou premissas de ineditismo de Gabeira também passavam ao largo do universo que a obra de Caio Fernando Abreu já havia tecido ao longo da década de 70.

\section{Caio e a rasura da fronteira}

Pode-se pensar inclusive que Caio é o antípoda de Gabeira, ou seja, Caio é a figura cuja extrema importância na reinvenção de masculinidades não hegemônicas é multiplicada pela sua modéstia e percepção pouco inflada do seu próprio papel. Quanto a essa importância de Caio, acerta em cheio Jaime Ginzburg quando diz que

embora seja conhecido por sua ficção intimista e pela sua incursão na temática do homoerotismo, Caio Fernando Abreu ainda está por ser compreendido em um de seus lados mais fortes: a política. Escritor de resistência, não sem contradições, Caio é responsável por alguns dos principais momentos de lucidez crítica com relação à opressão do regime militar, na ficção brasileira (Ginzburg, 2012, p. 405).

Entre a importante produção de Caio no período da ditadura militar cuja análise poderia nos aproximar da compreensão que Ginzburg reclama, está o conto "Ascensão e queda de Rhobéa, manequim e robô", uma ficção científica sobre masculinidades não hegemônicas publicada em $O$ ovo apunhalado (1975). O texto relata uma distopia resultante de uma praga tecnológica que mata "os contaminados". Os sobreviventes são perseguidos, expulsos e destruídos. Quando a comunidade aparentemente volta ao normal, o poder central passa a propagandear e vender partes metálicas dos corpos pertencentes à minoria supostamente extinta. Tudo funciona até que um jornalista encontra alguns possíveis sobreviventes. Inicialmente desqualificado com epítetos homofóbicos, ele prossegue na pesquisa, publica e em última instância tem sucesso, ao mostrar que o povo não havia mesmo se esquecido da "Praga Tecnológica". Um autointitulado "movimento tecnológico" se põe de moda e começa a gerar receitas para o país.

\footnotetext{
6 Para trabalhos mais exaustivos, ver Green $(1999,2006)$. Em estudos como os de Green, publicados nos anos 1990 e 2000, descortinam-se com mais detalhe várias práticas dos anos 1970 das quais alguém que fazia em 1980 os reclamos de ineditismo que fez Gabeira teria que ter tido pelo menos notícia.
} 
Enquanto isso, num canto escondido, os sobreviventes continuam a se reproduzir até que a polícia os encontra e os extermina, com exceção de uma jovem, Rhobéa, feita de aço e com olhos de vidro. Depois de ser lançada na prisão, sua trajetória segue o padrão estabelecido no conto: salva por um designer, ela se torna famosa e é eleita rainha das atrizes por cinco carnavais consecutivos, até que misteriosamente foge para uma ilha deserta na qual vive o resto dos seus dias. Aos rumores de que era lésbica, segue-se a publicação do diário de uma jovem, intitulado Minha vida com Rhobéa, que se torna um best-seller e leva a autora à indicação ao prêmio Nobel. O relato vai então seguindo um padrão, de exclusão seguida pela recuperação e cooptação. Quando chega a notícia de que Rhobéa cometeu suicídio, os seus restos mortais são embalsamados na praça, sua vida é lembrada em várias publicações, e as travestis passam a se inspirar nela.

Apesar de que o registro fantástico, alegórico, que encontramos nesta ficção científica não seria dominante na sua obra, "Ascensão e queda de Rhobéa" estabelecia alguns motivos que seriam reiterados na narrativa de Caio em diferentes estilos. Dedicado a Elke Maravilha, o conto põe em movimento uma dinâmica comum nas representações da exclusão na obra de Caio. A violência da marginalização, e não só a homofóbica, é representada de forma a não se limitar ao estatuto de denúncia. As histórias de Caio captam uma dialética entre exclusão e inclusão que costuma eludir a literatura mais ativista ou diretamente política. No caso de "Ascensão e queda de Rhobéa", no entanto, a alegoria política salta ao primeiro plano: os "contaminados" são expulsos e destruídos para depois ressurgirem. Rhobéa passa por horrores indizíveis, mas sobrevive como moda apropriada pela lógica do poder e transformada em emblema lucrativo. Isso não elimina nem cancela suas possibilidades contra-hegemônicas, mas exige a retirada para a ilha e a estigmatização como "homossexual". Exige um reposicionamento.

"Ascensão e queda de Rhobéa" mostra como os sujeitos excluídos por razões de identidade de gênero ou orientação sexual fazem da reapropriação uma de suas estratégias centrais. As travestis - membros de um dos grupos mais vulneráveis e perseguidos na sociedade brasileira e nas sociedades ocidentais - são as que mais adotam os traços da personagem principal popularizados pelo poder. Ao fazê-lo, elas os ressignificam e demonstram que a relação dos marginalizados com o poder não é de exclusão completa, se com isso pensamos que eles 
ocupariam uma posição de total exterioridade em relação a ele. Elas também transformam e são transformadas pelo poder, são engolidas e expulsas e de novo engolidas num movimento narrativo em espiral. "Ascensão e queda de Rhobéa" representa essa posição de masculinidade através de uma personagem associada à homossexualidade e a uma doença contagiosa, quase uma década antes da epidemia de AIDS, que vitimaria o seu próprio autor.

Apesar de que seus livros posteriores escolheriam registros distintos, Caio voltaria a explorar ambiguidades entre inclusão e exclusão, cooptação e subversão ao longo de sua trajetória. ${ }^{7}$ Já o seu primeiro livro de contos, Inventário do irremediável, retratava uma zona de indeterminação entre a hétero e a homossexualidade que acionava irrupções de homofobia mais nítidas que aquelas que reagem a práticas e identidades gays propriamente ditas. Um experimento com esse modelo de narrativa se intitula "Madrugada" e retrata o encontro entre dois homens no bar, ouvindo um ao outro "com a sabedoria dos que não têm nada para dar". Eles se identificam com a lucidez dos bêbados, imediatamente suspeitando que têm algo em comum. Como é de costume na ficção de Caio, essa comunidade inclui experiências dolorosas com as mulheres. Um deles suspeita que a noiva o está traindo. $\mathrm{O}$ outro foi casado e suspeita que as viagens da mulher eram desculpas para ver o amante. Ambos eram operários insatisfeitos. O narrador nos diz que "tudo neles era recíproco" e a intimidade entre eles começa a atiçar a homofobia dos outros homens no bar: "Não era permitido a duas pessoas se encontrarem e, ostensivas, humilharem a todos com sua infelicidade dividida" (Abreu, 2005, p. 111). A crescente hostilidade leva o dono do bar a se alinhar à maioria e pedir-lhes que saiam. O maior - de uns 1,90m - pensa em brigar, mas o outro, "mais fraco e portanto mais realista", convence-o de que não é de interesse deles. De braço dado, saem pela madrugada.

"Madrugada" põe em cena um caso depois bem reiterado na ficção de Caio: a homossocialidade, sem alusão a homoerotismo ou qualquer outra manifestação de masculinidade não hegemônica, provoca por si só um bombardeio de homofobia. A representação de uma zona de indeterminação entre homo e heterossexualidade desestabiliza,

\footnotetext{
7 Para uma análise da ficção de Caio em relação com a implantação do dispositivo da sexualidade, ver Leal (2002).
} 
chacoalha, sacode a ordem heteronormativa mais profundamente que um ativismo identitário gay. A representação da homofobia no conto ganha toda sua significação, naturalmente, do fato de que nenhum dos dois homens se identifica como gay e nada em sua interação autoriza o leitor a acreditar que sejam. Não há sequer sugestão de contato sexual ou sensual de qualquer tipo, mas a intimidade entre eles é suficiente para desatar uma reação homofóbica em pânico. Assim como os estudos críticos sobre raça demonstraram que o racismo não é a discriminação com base em uma noção previamente constituída de raça, mas o contrário, ou seja, que a própria invenção do conceito de raça é um capítulo na história do racismo. É comum em Caio que o relato sugira uma cena contraintuitiva, a saber, que a homofobia não depende em absoluto da, não mantém relação com, prática homossexual. Ela é engendrada por processos que não dependem em nada da proximidade de homens gay. Os dois personagens de "Madrugada" estabelecem uma relação que é única para cada um deles e criam um espaço no qual podem compartilhar experiências não compartilhadas antes. Algo sem precedentes acontece com seus afetos enquanto afetos masculinos. A incerteza e a instabilidade ao redor, que a cena produz no contexto heteronormativo e homofóbico, toma a forma de uma reação violenta. Nas ficções de Caio, mais que uma suposta identidade gay unitária e ativista, o que desestrutura a ordem heteronormativa é a rasura da fronteira entre homo e heteroafetividade. ${ }^{8} \mathrm{Na}$ cena em que se dá essa rasura produz-se o golpe mais duro contra a masculinidade hegemônica.

"Aqueles dois" mostra uma versão mais elaborada dessa cena. Tratase da penúltima história do livro Morangos mofados, volume de importância merecedora de algumas palavras a mais. Publicado em 1982 na coleção Cantadas literárias, da Brasiliense, Morangos mofados foi emblemático daquela inovadora série inaugurada por Luiz Schwarz. Com um design juvenil, estética pop, capas bem coloridas, formato inovador, a coleção lançou para um público mais amplo vozes como Ana Cristina César, Marcelo Rubens Paiva e Reinaldo Moraes, este último um bom amigo de Caio. Cantadas literárias foi uma série em claro

\footnotetext{
${ }^{8}$ Um amplo diálogo com esse efeito produzido pela obra ficcional abriu-se, claro, com a publicação em 2002 das Cartas de Caio, selecionadas e prologadas por Ítalo Moriconi. Como nota Moriconi, essas cartas cumprem efetivamente o papel de diário enquanto Caio administrava as oscilações de suas condições físicas e estados de ânimo (Moriconi, 2002, p. 13).
} 
diálogo com seu tempo, o da redemocratização, da consolidação dos movimentos de mulheres, afro-brasileiros(as) e LGBTs, assim como a emergência de estilos literários em consonância com uma sensibilidade pop. Os contos de Morangos mofados eram emblemáticos, já que lidavam com experiências como a descoberta sexual, a homofobia, o mundo do rock'n'roll, as drogas ou a desilusão imposta pela ditadura. A capa colorida e a linguagem informal e pop não impediria que o livro lidasse com as experiências mais traumáticas, nas quais o passado recente aparecia de forma fantasmagórica, como irrupção alucinatória. Como notou Jaime Ginzburg, em Morangos mofados, "silêncios, lapsos, ambiguidades e descontinuidades apontam constantemente para a implosão das condições necessárias para a clareza da fala, dando lugar a elaborações em que o detalhe impressionista, a metáfora e o ritmo assumem funções semânticas" (Ginzburg, 2005, p. 40). Foi o livro que catapultou Caio Fernando Abreu à condição de figura icônica de sua geração.

Em "Aqueles dois", um narrador em terceira pessoa algo distante nos diz que Raul e Saul foram contratados separadamente numa firma. Ele nos avisa que, apesar da discrição deles, "desde o princípio alguma coisa - fados, astros, sinas, quem saberá? conspirava contra (ou a favor, por que não?) aqueles dois" (Abreu, 1982, p. 127). Como em "Madrugada", os personagens estão saindo de relações frustradas com as mulheres. Raul vinha de um casamento fracassado de três anos, sem filhos, e Saul vinha de um "noivado tão interminável que terminara um dia". Eles não tinham ninguém na cidade e eram ambos estrangeiros naquela repartição, um "deserto de almas" ${ }^{9}$. Além do violão, Raul tinha um telefone alugado - índice daquele começo dos 80 marcado pelo aluguel de linhas telefônicas no Brasil -, um toca-discos e um sabiá de nome Carlos Gardel numa gaiola. Saul era proprietário de uma TV a cores com defeito, cadernos de desenho, tubos de tinta e um livro de reproduções de Van Gogh. Mais altos que seus colegas, "quando juntos eles aprumavam ainda mais o porte". Eram homens bonitos, que convidavam olhares das mulheres. Nenhum dos dois tinha pinta de alguém que carimba papéis oito horas por dia. Imperceptivelmente para si próprios, começam a se comportar como se existisse uma "estranha e secreta harmonia" entre eles, mas seu contato continua discreto, apesar de cordial.

${ }^{9}$ Como se trata de conto bastante curto, optamos por não acrescentar as referências às citações, para evitar repetição desnecessária de páginas. O mesmo vale para o conto de João Gilberto Noll “Cenas imprecisas”, analisado mais adiante 
Um dia Saul chega à repartição atrasado e sem se barbear, e conta que havia ficado assistindo a um filme, Infâmia (The children's hour), baseado em peça de Lillian Hellman, dirigido por William Wyler e no qual estrelam Audrey Hepburn e Shirley MacLaine. Para o leitor que conhece o filme, já se antecipa ali, en abyme, o tema do próprio conto, já que o filme narra o pesadelo vivido por duas professoras do ensino médio que são falsamente "acusadas" de serem lésbicas. Ninguém na repartição conhecia o filme, exceto Raul. Daí parte-se para o café e um dia compartilhado conversando sobre o filme. $\mathrm{O}$ cinema se torna um mediador na relação dos dois homens, e eles começam a desejar que os fins de semana passem depressa para que venha logo a segunda-feira que marca o reencontro. As mulheres da firma começam a planejar festas e eventos, mas eles continuam a sair juntos para falar de filmes. Depois dos primeiros drinks, finalmente conversam sobre os relacionamentos passados, fracassados, com mulheres. Os fins de semana se tornam tão longos que decidem trocar telefones. Tudo acontece bem devagar na história e o ritmo mais lento vai produzindo um efeito: a expectativa sobre o estreitamento do laço que os une. A chave da história passa a ser o fato de que nada ocorre ou, melhor dito, ocorre a homofobia antes que a homoafetividade sequer se consolide.

Numa tarde de domingo Saul decide ligar e fazer a primeira visita a Raul. Jantam juntos, conversam, trocam experiências. Raul toca o tango "Tú me acostumbraste" no violão e Saul faz amizade com o sabiá, Carlos Gardel. Retornam ao trabalho na segunda sem dizer nada um ao outro e, sem que percebam, os colegas começam o cochicho e a fofoca. No aniversário de Saul, Raul, sem um tostão, lhe presenteia a gaiola com Carlos Gardel. No aniversário de Raul, é a vez de Saul presenteá-lo com uma de suas próprias posses, a reprodução do Quarto em Arles, de Van Gogh. Agora Raul e Saul já passam os domingos juntos e um dia, por causa da chuva, Saul acaba passando a noite no sofá de Raul. Ao chegarem juntos na segunda-feira, de cabelo molhado, as mulheres deixam de se dirigir a eles. No começo de dezembro, com a morte da mãe de Raul, ele viaja por uma semana e Saul se vê incapaz de se concentrar no trabalho. Na volta de Raul, o apoio de Saul faz que ele enuncie as palavras mais ternas que trocam em todo o conto: "Eu não tenho mais ninguém no mundo", e logo depois um "Você tem a mim agora".

No Natal e no Ano Novo, eles de novo recusam os convites dos colegas e passam tempo juntos, trocando outro par de presentes 
significativos. Raul dá ao amigo a reprodução de $O$ nascimento de Vênus, de Botticelli, e Saul retribui com uma coletânea de Dalva de Oliveira. Depois da festa de Ano Novo, eles bebem, vão para o quarto, se despem juntos, elogiam o corpo um do outro e deitam-se em camas separadas, incapazes de dormir, observando o cigarro que o outro acende. Não demora muito para que o chefe os convoque a uma reunião em que relata ter recebido cartas que falavam de uma relação "anormal", um "escândalo" de "psicologia deformada". As cartas vinham assinadas por um "Guardião da Moral". Antes que pudessem dizer qualquer coisa, são despedidos. Esvaziam suas gavetas, partem e, quando Raul abre a porta do táxi para Saul, alguém faz uma brincadeira homofóbica da janela. A repartição aparentemente volta à normalidade. As últimas frases do conto são implacáveis: "Quase todos ali dentro tinham a sensação de que seriam infelizes para sempre. E foram".

A temporalidade do relato é curiosa. Os marcos na relação de Saul e Raul - as primeiras conversas, as visitas, a escolha de se manterem distantes dos colegas, a primeira troca de presentes etc. - se espalham pela superfície do texto como a criar um tempo alongado, apesar de "Aqueles dois" ser um conto curto, de 2.800 palavras. Eles são despedidos antes das primeiras férias, em janeiro, o que sugere que estavam completando um ano no emprego. $O$ tempo acelera ou se arrasta segundo o que lhes acontece: cinco dias num escritório brutalmente desumanizador passam depressa na medida em que afloram seus sentimentos pelo outro, enquanto um mero fim de semana parece intolerável e longo antes que comecem as visitas dominicais. Por outro lado, há uma temporalidade própria à homofobia. As mulheres da repartição aos poucos passam de tentar seduzi-los a ignorá-los por completo, enquanto os homens começam na tentativa de "sacar qual é a deles" e passam a uma atitude abertamente hostil. A temporalidade da homofobia na história pode ser exemplificada com referência à proposta de Ricardo Piglia em suas "Tesis sobre el cuento", de que um conto sempre narra duas histórias (Piglia, s/d). Os estilos e traços pessoais dos vários autores dependeriam de como decidem relacionar a história 1 e a história 2, a história de superfície e a história secreta. Se estabelecemos que a história 1 desenvolve a relação homoafetiva entre Raul e Saul e a história 2 retrata o pânico homofóbico na repartição, o que é mais notável no conto de Caio é que a história 1 não precede a história 2 . Ou seja, a natureza da relação que os ata não é determinada imanentemente, 
mas à luz da pressão do preconceito e da discriminação. Não costuma haver, nos contos de Caio, qualquer homoafetividade consolidada previamente à emergência da homofobia. O conto coloca as duas histórias em diálogo, mas a segunda - a homofobia que vai se constituindo no escritório - serve de mola propulsora da resolução da trama.

Como seria de se esperar, os artefatos culturais citados no conto adquirem, todos eles, função simbólica. O filme que inicia a relação dos dois, Infâmia, replica en abyme o destino dos personagens, perseguidos pela homofobia. No caso do filme, a acusação de que as professoras Martha e Karen teriam tido relações lésbicas termina sendo ainda mais devastadora e leva Martha ao suicídio. Para qualquer leitor com uma formação mínima na literatura nacional, o sabiá do conto evocará a "Canção do exílio", de Gonçalves Dias, marco da poesia romântica nostálgica e imagem por excelência da saudade e do desejo de domesticidade. Tampouco surpreende que a canção escolhida por Raul para o violão seja o bolero "Tú me acostumbraste", de autoria do cubano Frank Domínguez, melancólico e evocativo de um amor que transforma uma vida. O próprio nome do sabiá, Carlos Gardel, evoca também o universo do tango, gênero popular todo construído em torno a um mundo masculino do lamento e as relações frustradas com mulheres.

A reprodução de Van Gogh, guardada no quarto de Saul e depois dada a Raul com presente de aniversário, é descrita como "aquele quarto com a cadeira de palhinha parecendo torta, a cama estreita, o chão de madeira". A alusão é clara a Quarto em Arles, óleo sobre tela em três versões, a primeira de 1888, que retrata a alcova de Van Gogh na praça Lamartine, 2, em Arles, Bouche-du-Rhône. Trata-se da pintura mais emblemática do período da espera de Van Gogh pela chegada de Paul Gauguin a Paris. É considerável a especulação sobre a relação homoafetiva entre Van Gogh e Gauguin, assim como sobre a possível condição de Van Gogh de homem gay no armário. A pintura, em todo caso, retrata a espera de um homem por outro homem e um quarto, e isso é o que importa e basta aqui. Em carta de 16 de outubro de 1888 a seu irmão Theo, Vincent Van Gogh dizia que gostaria que as cores fizessem tudo no quadro. O quarto com a cama, a mesa de cabeceira, as duas cadeiras em tons básicos, tudo reforça a sensação de solidão e espera. Tanto na pintura como na música, a relação de Saul e Raul encontra alegorias que vão sendo trocadas: Saul fica com a letra de "Tú 
me acostumbraste", copiada por Raul, enquanto este fica com a reprodução de Van Gogh que pertencera a Saul.

Ao contrário de boa parte da literatura gay mais ativista, a ficção de Caio não retrata nunca a saída plena do armário ou a tomada de consciência. Não costuma haver nada de muito heroico na trajetória dos personagens de Caio. No caso de "Aqueles dois", fundamental para o efeito da história é o fato de que sabemos que os personagens não se identificam como gays e, se os leitores e os colegas de repartição não sabem qual é a natureza daquilo que os une, eles tampouco o sabem. Estão atados por um afeto que ainda não tem nome: "Não tinham preparo algum para dar nome às emoções nem mesmo para tentar entendê-las". Essa zona de indeterminação acaba sendo enlouquecedora para os colegas de escritório, que assumem a posição de guardiões da ordem heteronormativa. Mais ameaçador para essa ordem não é, portanto, a possível presença de dois homens gays, mas o fato de que a fronteira supostamente estável entre homo e heterossexualidade parece se desfazer. O que deixa os colegas enfurecidos é o fato de que não sabem compartimentalizar as identidades sexuais de Raul e Saul, mas a ironia extra do conto, claro, advém de que os dois personagens tampouco o sabem, ou pelo menos o relato não nos oferece indícios de que o saibam. É precisamente pela falta de conhecimento de Raul e Saul acerca de sua própria identidade - sua condição de significantes vazios, por assim dizer - que eles passam a assumir múltiplos sentidos para aqueles ao seu redor. No minuto em que a chegada de dois homens possivelmente gays obriga os colegas a falar do assunto, desmorona o pacto tácito sobre o que significa ser homem e eles reagem com violência. A literatura de Caio mostra que um dos requisitos para que se mantenha um edifício estável da masculinidade é o silêncio em torno aos rituais que a sustentam.

\section{Noll e o sumiço do pai}

A relação com o pai e as imagens de putrefação e decadência, que seriam reiteradas na obra posterior de João Gilberto Noll, apareceriam já em "Cenas imprecisas", relato de $O$ cego e a dançarina que capta dimensões fundamentais da vida no Brasil sob ditadura militar. "Cenas imprecisas" oferece um impactante cenário pós-apocalíptico advindo de uma represa: “E a cidade? Olho-a também abandonada porque este rio 
avançará e não deixará uma única casa. Os habitantes se foram. Dizem que a construção de uma represa obrigou a isso" (Noll, 1986 [1980], p. 92). A profecia é acompanhada da descrição da destruição acontecida. A voz do garoto que narra a história no primeiro parágrafo do conto alterna trechos no futuro e no pretérito, e se situa num presente que vive os efeitos da catástrofe que já aconteceu ("não vemos ninguém neste cais deserto") e no qual outra catástrofe é anunciada como iminente ("daqui a pouco virão os funcionários da Construtora para desferir os últimos golpes preparativos antes do afogamento da cidade"). Esse parágrafo, que abre o conto em primeira pessoa, é narrado pelo filho antes de que o texto, abruptamente, sem nenhuma indicação tipográfica ou de pontuação, passe à terceira pessoa que será a forma narrativa até o final. O filho estrangula uma mulher durante a cópula, deixa uns versos que preveem o afogamento da cidade e termina tragado pelas águas. O pai é um ex-fazendeiro que agora "explora mulheres, e os homens que frequentam seu bordel prestam serviços descabidos para pagar os desejos". O conto será, então, a história da realização dessa profecia e da busca policial pelo personagem, culpado de assassinato. A busca se dá no bordel de propriedade do pai do rapaz profeta.

A figura do profeta louco, de longa história na contística brasileira, de Machado de Assis a Murilo Rubião, aparece encarnada nesse personagem contra-hegemônico:

Mesmo sendo filho dos donos dessas terras, preferiram me ver como um louco, e meu pai foi o primeiro a atrair o internamento. $\mathrm{O}$ sanatório ficava em Rio D'Aurora, a 80 quilômetros daqui. Daqui a pouco virão os funcionários da Construtora para desferir os últimos preparativos antes do afogamento da cidade (Noll, 1986 [1980]).

Noll introduz essa figura no cenário surreal, alucinatório do barragismo promovido pela ditadura militar, compondo em seu relato o sombrio panorama que acompanha o negócio da construção de represas: a precarização do trabalho, o onipresente bordel, a força policial, remoções e um rastro de promessas.

"Cenas imprecisas" retrata os sobreviventes da hecatombe impossibilitados de "se integrar nos trabalhos reservados a eles", enquanto "sonham com mentiras, vivem deitados pelos cantos, se coçando, se maldizendo". Fica clara a menção às promessas da indústria barrageira às suas vítimas. No cenário eminentemente masculino construído por "Cenas imprecisas", no bordel do pai, ex-dono de terras, 
ele força os clientes a que "contrabandeiem armas, se suicidem para incriminar os capangas do prefeito e gozem nas mulheres doze vezes seguidas". Na atmosfera, tom e cenário claustrofóbico e alucinatório, "Cenas imprecisas" recorda relatos publicados alguns anos antes por J.J. Veiga, mas enquanto em Veiga se vislumbrava uma origem fantástica da história, como na invasão de bois que ocupam a cidade em A hora dos ruminantes, Noll parte de uma origem mimeticamente plausível, a construção da represa, e vai compondo uma cena de terror que bordeja a inverossimilhança mágico-fantástica.

Na carta profética deixada pelo garoto louco tragado pelas águas, ele antecipava não só o afogamento da cidade, mas a cena em que os policiais se encontrariam com seu pai, este maldiria "o nome sórdido do meu filho" e desejaria que ele fosse "comido pelos bichos por aí". A cena teria um final previsível: "o pai acalmaria o povo e os policiais oferecendo a todos uma festa no bordel onde só não seria permitido a penetração anal em homens". O interdito homofóbico caminha de mãos dadas com a indústria da prostituição fomentada pelo barragismo, que arrasta uma legião composta por homens que viajam sós. Na carta do filho, mais marcantes que a previsão seriam "o óbvio disso tudo" e a ideia de que "sua morte [do pai] seria um ato de extrema contestação ao óbvio da vida". Quando o protagonista escreve na carta que "sei de cor todos os passos do destino da cidade. Eu quero um outro teatro [...] porque este eu conheço não sei quantos milhares de vezes", é como se Noll dissesse ao desenvolvimentismo brasileiro e às suas ilusões de progresso: "este filme nós já vimos e eis aqui como ele termina".

Depois da orgia, o pai também amanhece morto, "os policiais presumiram que envenenado". Segue-se o massacre que cerra o círculo dantesco, quando a polícia busca o jovem que havia assassinado a mulher. O assassino já havia sido levado pelas águas:

No meio daquele povo arrotando azedumes da noite, estirado pelo chão e dormente de ressaca, os policiais descobriram que seria impossível encontrar o criminoso. E eles não tinham tempo de ficar mais um dia na cidade. Então resolveram fazer justiça com suas próprias mãos (Noll, 1986 [1980]).

O conto conclui com a impressionante imagem de uma longa mesa com o cadáver do pai, rodeada pelo povo do lugar. "[M]as não era como qualquer morto, ele roncava como se ainda estivesse no sono da ressaca, arrotando gases apodrecidos, sons engrolados, rajadas de blasfêmias". 
É como se a imagem do cadáver do pai carregasse em si toda a podridão da história, toda a desolação do lugar, toda a violência pretérita. A cena que precede "o fuzilamento de todos os suspeitos ou quase todos", essa imagem de "réus desguaridos e policiais prometendo matar diante de um morto que ronca", poderia ser tomada como uma alegoria composta pelos restos, frangalhos, cadáveres deixados para trás ("o filho apodrece sem sepultura ou qualquer testemunha que não os urubus") no Brasil potência que se expande durante a década de 1970 sob a ditadura militar. O conto se reveste de uma impressionante atualidade na primeira metade da década de 2010, em que o barragismo e o projeto desenvolvimentista para a Amazônia do governo Dilma Rousseff retomam a geopolítica de Golbery do Couto e Silva, o formulador da concepção de Amazônia adotada pelos algozes da ex-guerrilheira e atual presidenta.

A representação do pai em "Cenas imprecisas" faz de sua figura uma espécie de fardo da história no contexto do desenvolvimentismo arrasa-quarteirão do regime militar. O filho prevê que o pai "será regiamente indenizado" e "comprará outras terras, terá outras riquezas", e o pai diz aos policiais que buscam o garoto pelo assassinato que "não quero que falem nesse nome sórdido do meu filho". Ou seja, pai e filho estão a destempo um do outro, separados por uma fissura. Ao contrário de "Alguma coisa urgentemente", conto da mesma coleção em que Noll também retrata uma relação entre pai e filho, mas no qual aquele é um guerrilheiro contra a ditadura militar, "Cenas imprecisas" retrata um pai que é cúmplice, e não opositor da ordem estabelecida. A carta deixada pelo filho se desmancha com a primeira chuva e não é vista por ninguém, mas ali se prevê um desenlace em que o pai "acalmaria o povo e os policiais oferecendo uma festa no bordel". Só não prevê a impossível morte do pai, provavelmente por envenenamento, em que o cadáver permanece como objeto público, sacrificial rodeado pelos sobreviventes e pela polícia. Ainda que por envenenamento e não por violência, o fato de ter sido cúmplice do projeto não impede que o pai de "Cenas imprecisas" tenha o mesmo fim do pai em "Alguma coisa urgentemente": a degeneração do corpo seguida de morte, em um caso prevista, no outro testemunhada pelo filho.

Com contos como "Alguma coisa urgentemente" e "Cenas imprecisas", Noll inicia uma espécie de autópsia da masculinidade hegemônica, ainda mais incisiva pelo fato de enfrentar-se com o legado 
da ditadura militar sobre a decomposição dessa masculinidade. Em todo caso, tanto Gabeira como Caio como Noll apresentam respostas bem elaboradas a essa ruína: em todos eles se produz uma rasura, um borramento na fronteira entre a hétero e a homoafetividade e/ou sexualidade. Se em Gabeira ela é alardeada como mais pioneira e desestabilizadora do que realmente foi, em Caio ela parece ter sido mais política do que faria crer a imagem do escritor intimista. A ditadura, que impôs uma concepção tão fálica de mundo, representou também o começo da ruína de uma imagem hegemônica do masculino. Ou ajudou a tornar visível uma ruína que talvez já tivesse vindo de longe, da própria invenção da masculinidade enquanto tal, sempre acossada por uma crise que se confunde com sua própria existência.

\section{Referências}

ABREU, Caio Fernando (1975). O ovo apunhalado. Porto Alegre: Globo. (1982). Morangos mofados. São Paulo: Brasiliense.

(2002). Cartas. Organização de Ítalo Moriconi. Rio de Janeiro: Aeroplano. (2005). Caio 3D: O essencial da década de 1970. Rio de Janeiro: Agir.

AVELAR, Idelber (2012). Fernando Gabeira y la crítica de la masculinidad: la fabricación de un mito. In: El lenguaje de las emociones: afecto y cultura en América Latina. Edição de Ignacio Sánchez Prado e Mabel Moraña. Madri: Iberoamericana; Frankfurt: Vervuert.

CONNELL, Raewyn W. (2005 [1995]). Masculinities. 2. ed. Berkeley, Los Angeles: University of California Press.

COSTA, Albertina de Oliveira et al. (Orgs.) (1980). Memórias das mulheres do exílio. Rio: Paz e Terra.

DALCASTAGNÈ, Regina (1996). O espaço da dor: o regime de 64 no romance brasileiro. Brasília: Editora UnB.

GABEIRA, Fernando (1980). Crepúsculo do macho. Rio de Janeiro: Codecri. (1981). Entradas e bandeiras. Rio de Janeiro: Codecri.

(1981 [1979]). O que é isso, companheiro?. 21. ed. Rio de Janeiro: Codecri. 
GINZBURG, Jaime (2005). Exílio, memória e história: notas sobre “Lixo e purpurina" e "Os sobreviventes" de Caio Fernando Abreu. Literatura e sociedade, São Paulo, n. 8, p. 36-45.

(2012). Crítica em tempos de violência. São Paulo: EDUSP.

GREEN, James (1999). Beyond Carnival: male homossexuality in twentiethcentury Brazil. Chicago, Londres: University of Chicago Press.

(2006). Frescos trópicos: fontes sobre a homossexualidade masculina no Brasil (1870-1980). Rio de Janeiro: José Olympio.

LEAL, Bruno Souza (2002). Caio Fernando Abreu, a metrópole e a paixão do estrangeiro: contos, identidade e sexualidade em trânsito. São Paulo: Annablume.

MORICONI, Ítalo (2002). Introdução. In: ABREU, Caio Fernando. Cartas. Rio: Aeroplano.

Noll, João Gilberto (1986 [1980]). O cego e a dançarina. 2. ed. Porto Alegre: L\&PM.

PIGLIA, Ricardo (s/d). Tesis sobre el cuento. In: Crítica y ficción. Buenos Aires: Siglo XX, Universidad Nacional del Litoral.

RIDENTI, Marcelo et al. (1997) Versões e fiç̧ões: o sequestro da história. São Paulo: Perseu Abramo.

SÜSSEKIND, Flora (1985). Literatura e vida literária. São Paulo: Zahar.

Recebido em dezembro de 2013.

Aprovado em fevereiro de 2014.

\section{resumolabstract}

\section{Revisões da masculinidade sob ditadura: Gabeira, Caio e Noll}

Idelber Avelar

Este artigo analisa operações sobre a masculinidade realizadas por textos de Fernando Gabeira, Caio Fernando Abreu e João Gilberto Noll da passagem da década de 1970 para a de 1980. No Brasil a abertura política coincidiu com a consolidação do movimento gay, a lei do divórcio, o começo da entrada massiva das mulheres de classe média à força de trabalho remunerada, maior visibilidade das travestis e, no geral, a decadência de um modelo de homem promovido pelo regime militar. $\mathrm{O}$ ensaio discute as formas em que Gabeira, Caio e Noll rememoram, antecipam, alegorizam, atravessam e/ou ignoram esse contexto, e assim se situam de diversas maneiras na revisão da masculinidade que se produzia naquela virada de década. Gabeira escreve uma hipérbole sobre 
o seu próprio papel que termina se autorrealizando; Caio chega ali ao ápice de uma metódica desmontagem da fronteira entre homo- e heteroafetividade; Noll inaugura o que seria um trabalho de três décadas e meia de reflexão sobre a decomposição da masculinidade, através da representação de uma de suas cenas constitutivas, o sumiço do pai.

Palavras-chave: Noll, Gabeira, Caio Fernando Abreu, masculinidade, homofobia, homoafetividade, ditadura.

\section{Reviews of masculinity under dictatorship: Gabeira, Caio and Noll}

Idelber Avelar

This article addresses the coding of masculinity in texts by Fernando Gabeira, Caio Fernando Abreu, and João Gilberto Noll at the turn of the 1970s/1980s. In Brasil the Abertura period coincided with the consolidation of the gay movement, divorce laws, the beginning of the massive incorporation of middleclass women to the wage labor force, increasing visibility of transvestites, and overall the marked decadence of the ideal man promoted by the military regime. This essay discusses the ways in which Gabeira, Caio, and Noll remembered, anticipated, allegorized, cut through, and/or ignored that context, and thus situated themselves in different ways vis-à-vis the revision of masculinity that took place at the turn of that decade. Gabeira wrote a hyperbole that became self-fulfilling, Caio reached the pinnacle of career marked by a methodic erasure of the border between homo- and heteroaffectivity, and Noll inaugurated a three-decade-long reflection on the dissolution of masculinity through the representation of one of its constitutive scenes, the disappearance of the father.

Keywords: Noll, Gabeira, Caio Fernando Abreu, masculinity, homophobia, homoaffectivity, dictatorship. 